Ecology, 0(0), 2020, e03032

(C) 2020 by the Ecological Society of America

\section{Hitching a ride on Hercules: fatal epibiosis drives ecosystem change from mud banks to oyster reefs}

\author{
Ian M. McLeod id ${ }^{1,5}$ Gideon Heller-Wagner, ${ }^{1}$ \\ Chris Gillies, ${ }^{1,2}$ Lisa Boström-Einarsson id ${ }^{1,3}$ And \\ PATRICK G. DWyer iD 4
}

Manuscript received 9 December 2019; revised 23 January 2020; accepted 6 February 2020. Corresponding Editor: John Pastor.

${ }^{1}$ TropWATER (Centre for Tropical Water and Aquatic Ecosystem Research), James Cook University, Townsville, Queensland 4811 Australia.

${ }^{2}$ The Nature Conservancy, Carlton, Victoria 3053 Australia.

${ }^{3}$ Lancaster Environment Centre, Lancaster University, Lancaster LA1 4YQ United Kingdom.

${ }^{4}$ Coastal Systems, DPI Fisheries, 1243 Bruxner Highway, Wollongbar, New South Wales 2477 Australia.

${ }^{5}$ E-mail: ian.mcleod@jcu.edu.au

Citation: McLeod, I. M., G. Heller-Wagner, C. Gillies, L. Bostrom-Einarsson, and P. G. Dwyer. 2020. Hitching a ride on Hercules: fatal epibiosis drives ecosystem change from mud banks to oyster reefs. Ecology 00(00):e03032. 10.1002/ecy.3032

Best known as a "love them or hate them" luxury food, or for their pearls, oysters are also ecosystem engineers, forming vast oyster reefs. Oyster reefs provide habitat for a myriad of species, and support fisheries, improve water quality and provide coastal protection. These services are estimated to be worth US\$5,500$\$ 99,000$ per hectare per year (Grabowski et al. 2012). Globally, oyster reefs have declined by $85 \%$ through destructive overfishing, coastal development, pollution, and introduced competitors, predators and diseases (Beck et al. 2011). Active restoration is becoming an increasingly popular tool to bring back lost oyster reefs and the ecosystem services they provide (Fitzsimons et al. 2019). However, restoration is not always successful, and knowledge about how reefs naturally form and function is vital to improve restoration success. Oyster larvae only settle on hard substrates. Reefs proliferate because oyster shells provide a settlement surface, and oysters provide chemical and sound cues that facilitate larval settlement (Lillis et al. 2013). However, these reefs often form on intertidal sand and mud banks. This raises the question, how do oyster reefs form on mud banks in the absence of hard surfaces?
During research on the structure and population dynamics of remnant oyster reefs in Australia (McLeod et al. 2019), we observed many Hercules club mud whelks (Pyrazus ebeninum) with oysters growing on their shells (Fig. 1, Video S1). These whelks are one of the most common large marine snails on the east coast of Australia. They grow to $100 \mathrm{~mm}$ in length and feed on detritus and algae that grow on mud. We observed that individual whelks sometimes carried up to four large oysters on their shell, and as the oysters grew larger, it appeared that the whelks moved slower, and were pushed lower into the mud. We presumed that this would eventually lead to the death of the whelk and the formation of a new oyster clump. Evidence to support this presumption was gained when we investigated clumps of live oysters and found there was often a dead whelk shell in the center.

We searched for evidence of this process in the contemporary literature, and no record of whelks as a settlement habitat for oysters was found. Historical literature can be useful to regain information about historical baselines, especially when remaining reference ecosystems are degraded (McClenachan et al. 2012). By reviewing historical newspaper articles and fisheries reports some anecdotes were found (Smith 1985). Fison (1887) reported "the best oysters, in clumps of four to five, each contain a whelk $\sim 1.5-3$ inches long attached to them by the back [...], as the oysters increase in size more recruits attach until the whelk is buried and dies." Saville-Kent (1891) similarly noted "bank oysters may attach to rocks, dead shell known as cultch or as more frequently, attach to the shell of the Hercules whelk, [...] and are ferried to various areas of the feeding grounds, until the whelk is overwhelmed and dies from the

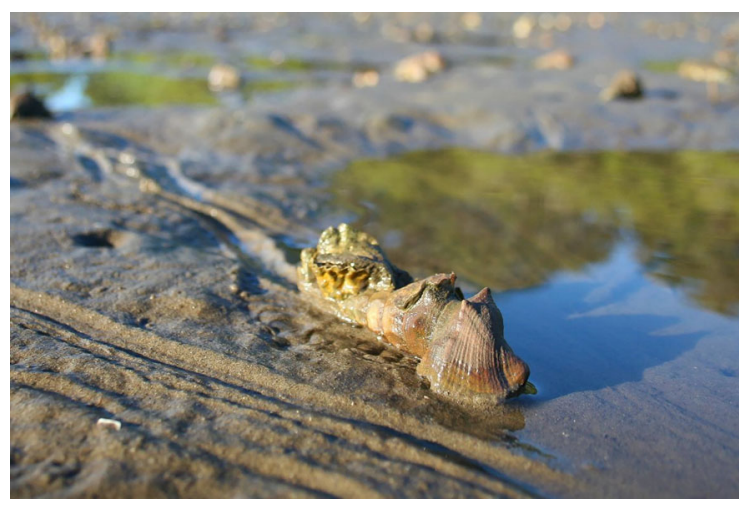

FIG. 1. A Hercules club mud whelk (Pyrazus ebeninum) with three oysters growing on its shell on a mud bank in Richmond River, New South Wales, Australia. Photo by Patrick Dwyer on 17 October 2015 at $28^{\circ} 50^{\prime} 55.4^{\prime \prime}$ S; $153^{\circ} 34^{\prime} 22.3^{\prime \prime}$ E. 
burden." An archaeological investigation into 1,000year-old Aboriginal rubbish heaps (middens) in southeast Queensland found that 7\% of oyster valves showed evidence of being attached to Hercules whelks (Smith and McNiven 2019).

Complex physical habitat in coastal systems like rocky shores, subtidal reefs and mangrove roots are largely fixed in space and hence are a bottom-up limiting force for associated sessile invertebrates and reef associated communities. We hypothesize that Hercules whelks play a unique facilitative role for oysters as ecosystem engineers in sediment-dominated estuarine environments through epibiosis. Epibiosis is a relationship between two organisms, of which one lives on the other, but is not parasitic. Epibiosis differs from other interspecies relationships (Fig. 2). For example, unlike parasitism, where one partner derives resources at the cost of the other, the majority of epibiotic organisms are facultative, and will attach to a wide range of hosts or inanimate hard surfaces (Wahl and Mark 1999). In contrast, both partners benefit in mutualism, while one partner benefits and the other is unaffected in commensalism. In amensalism, one partner is negatively affected but the other does not derive benefit nor harm.

There are thousands of examples of marine epibiosis that range from barnacles growing on whales and microcolonizers such as bacteria and algal spores (Harder

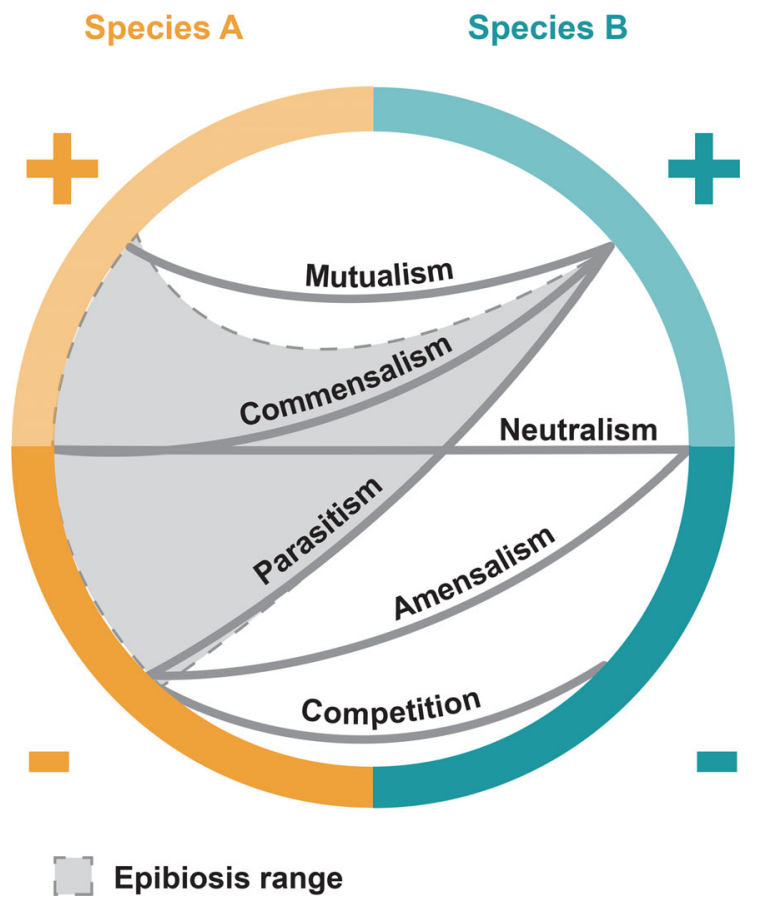

FIG. 2. Interspecies relationships (i.e., symbioses) can take many forms, depending on the benefits and harm caused by the two species. The shaded area represents the potential range where epibiosis fits in to this schematic.
2009). Epibiosis often harms host organisms by shading, increasing mass and friction, reducing access to dissolved molecules, or through "shared doom" by encouraging predation or herbivory (Wahl 1989). Conversely, hosts may benefit due to camouflage and protection against drying out, reduced friction, or provision of physical defence. In the absence of hard surfaces on mud banks, epibiosis provides the only way for oysters to expand into these habitats. Subsequent generations of oyster larvae can then settle on oyster shells creating a self-sustaining ecosystem, no longer reliant on whelks as substrate. The Hercules-oyster relationship is significant because it appears to be facultative for an entire ecosystem and not just individuals.

Epibiosis as a driver of ecosystem change is likely to be under-recognized in the marine environment. For example, Pacific oysters are invasive in the Dutch Wadden Sea, and have overgrown and replaced native blue mussel (Mytilis edulis) beds by settling on their shells (Eschweiler and Christensen 2011). Pacific oysters also grow on the shells of the gastropod Littorina littorea (Periwinkles), reducing their ability to move and reproduce (Eschweiler and Buschbaum 2011). While the interaction between Hercules whelks and oysters is a similar process to these examples, the Hercules whelks and oysters are both native species in Australia. Therefore this is likely to be a natural process, as described in the historical literature. Only $10 \%$ of former oyster reefs remain in Australia (Gillies et al. 2018) and these ecosystems are often replaced by "bare" soft sediments, with markedly less three-dimensional structure and habitat value (McLeod et al. 2019). Oyster restoration is rapidly scaling up in Australia, however there are few natural reference sites left to study to show how these ecosystems function (Gillies et al. 2018). This study shows the importance of understanding ecological processes including epibiosis, particularly in the context of the growing field of restoration. Further, it emphasizes the importance of going beyond the contemporary scientific literature in a rapidly changing world to include historical context from scientific naturalists for baselines and understanding natural ecosystem function.

\section{Literature Cited}

Beck, M. W., R. D. Brumbaugh, L. Airoldi, and A. Carranza. 2011. Oyster reefs at risk and recommendations for conservation, restoration, and management. BioScience 61:107-116.

Eschweiler, N., and C. Buschbaum. 2011. Alien epibiont (Crassostrea gigas) impacts on native periwinkles (Littorina littorea). Aquatic Invasions/European Research Network on Aquatic Invasive Species 6:281-290.

Eschweiler, N., and H. T. Christensen. 2011. Trade-off between increased survival and reduced growth for blue mussels living on Pacific oyster reefs. Journal of Experimental Marine Biology and Ecology 403:90-95.

Fison, C. S. 1887. Report on the oyster fisheries of Moreton Bay. Queensland Parliament, Brisbane, Queensland, Australia. 
Fitzsimons, J., S. Branigan, R. D. Brumbaugh, T. McDonald, and P. S. E. zu Ermgassen, editors. 2019. Restoration guidelines for shellfish reefs. The Nature Conservancy, Arlington, Virginia, USA.

Gillies, C. L., et al. 2018. Australian shellfish ecosystems: Past distribution, current status and future direction. PLoS ONE 13:e0190914.

Grabowski, J. H., R. D. Brumbaugh, R. F. Conrad, A. G. Keeler, J. J. Opaluch, C. H. Peterson, M. F. Piehler, S. P. Powers, and A. R. Smyth. 2012. Economic valuation of ecosystem services provided by oyster reefs. BioScience 62:900-909.

Harder, T. 2009. Marine epibiosis: concepts, ecological consequences and host defence. Pages 219-231 in H.-C. Flemming, P. S. Murthy, R. Venkatesan, and K. Cooksey, editors. Marine and industrial biofouling. Springer, Berlin, Germany.

Lillis, A., D. B. Eggleston, and D. R. Bohnenstiehl. 2013. Oyster larvae settle in response to habitat-associated underwater sounds. PLoS ONE 8:e79337.

McClenachan, L., F. Ferretti, and J. K. Baum. 2012. From archives to conservation: why historical data are needed to set baselines for marine animals and ecosystems. Conservation Letters 5:349-359.
McLeod, I. M., et al. 2019. Habitat value of Sydney rock oyster (Saccostrea glomerata) reefs on soft sediments. Marine and Freshwater Research. (Online Early).

Saville-Kent, W. 1891. Oysters and oyster-culture in Australasia. Australasian Association for Advancement of Science 3:550-573.

Smith, G. S. 1985. The Queensland oyster fishery: An illustrated history. Queensland Department of Primary Industry, Brisbane, Australia.

Smith, T., and McNiven, I. J. 2019. Aboriginal marine subsistence foraging flexibility in a dynamic estuarine environment: The late development of Tin Can Inlet (southeast Queensland) middens revisited. Queensland Archaelogical Research 22:1-38. https://doi.org/10.25120/qar.22.2019.3670

Wahl, M. 1989. Marine epibiosis. I. Fouling and antifouling: some basic aspects. Marine Ecology Progress Series 58:175-189.

Wahl, M., and O. Mark. 1999. The predominantly facultative nature of epibiosis: experimental and observational evidence. Marine Ecology Progress Series 187:59-66.

Additional supporting information may be found in the online version of this article at http://onlinelibrary.wiley.com/doi/10. 1002/ecy.3032/suppinfo 